\title{
A Slow Train Crash That Can Be Avoided: Citizen Power, the Mining of Critical Raw Materials (CRMS) Within Europe and the Need for Investment in Political Realities
}

\author{
Mark R. Proctor \\ Sazani Consulting
}

The EU requires Critical Raw Materials (CRMs) and recognises that failure to access them within its jurisdiction, will damage its resilience and competitiveness. Additionally, this will force EU industries to purchase CRM materials from unsavoury social and environmental weak jurisdictions. By failing to develop a taxonomy for mining in the Green Deal, the EU invites social and political conflict, through the creation of critical Social Licence to Operate (SLO) situations around new and developing mining projects in Europe. SLO is represented by Proctor's (2021) Social Licence Settlement Model (SLSM) as a type of political settlement. Defining that term in this way, enables a range of essential relationships to be mapped. Once essential relationships within a dynamic model for SLO are represented relationally, it becomes possible to explore the factors shaping those interactions and ultimately investigate the designing of metrics. In this context the SLSM model illustrates the urgent need for the EU to develop a range of systems and approaches for engaging citizens around potential and developing mining projects.

Keywords: mining, social licence to operate (SLO), conflict, critical raw materials (CRMS), political settlement, European Union

\section{INTRODUCTION}

The year 2020 brought the world to a near standstill, with the global pandemic highlighting the fragility of a globalised economy and drew attention to the need for resilience at an EU level, including around the sourcing of minerals needed to support a greener future. These particular minerals have been termed Critical Raw Materials (CRMs). In Europe we are facing a paradoxical situation, where demand is high and exploration resources are available, but societal and political reluctance hinders entrepreneurship and investment in the exploration/extractives sector (Proctor and MacCallum 2020, Endl 2019). Globally mining activities are often regarded as destructive and unsustainable and innovations within the sector offering prospective solutions are currently facing an increasingly complex and hostile social context ( Bice, Brueckner, \& Pforr, 2017, Lacey, Malakar, McCrea, \& Moffat 2019, Mason et al., 2014; Moffat et al., 2018; van der Plank et al., 2016). Negative events at a local level can affect public views of mining generally at a regionally or even at a transnational level. This can be seen in Serbia as media draws parallels between Rio Tinto's cultural vandalism in Australia regarding their Jadar mine developments in western Serbia (Media 1). Access to and sustainable utilisation of Critical Raw Materials (CRMs) such as rare earths, have been identified as a key prerequisite to achieving the ambitious targets set out in the EU Green Deal. The 
European Commission Joint Research Centre produced a report entitled Critical Raw Materials for Strategic Technologies and Sector (Bobba 2020:79) detailing that.

"these materials are the basis for all industrial value chains and ultimately contribute to societal well-being to secure current and future supply of materials"

A Circular Economy is seen by many as the goal but, for now, the EU acknowledges that critical raw materials still need to be produced via mining and, for this to happen, considerable changes in societal practices and in the behaviour of individuals, communities, and public and private organisations are required (ibid). European's face a stark choice in decarbonising its economy (Herrington 2021). Either they find mechanisms for obtaining these CRMs from under the ground in Europe, negotiating the gathering SLO storm from communities distrustful of the mining sector, or they rely of CRM material from localities where the social and environmental impacts are less likely to be regulated, China, Democratic Republic of Congo to name a couple. If the EU do the former, they can theoretically erect trade barriers against imported minerals and their products, driving positive change within the CRM supply sector globally from environmental and social perspectives. Strategically then, EU's industries and producers could become more insulated from trade conflicts relating to CRMs. Conversely, failure to facilitate access to CRMs in Europe will increases business and political vulnerabilities within the EU from the inevitable fall out of dealing with the outcomes of utilising CRM materials from poorly regulated social and environmental systems.

Research within Europe reinforces a pessimistic view of the factors creating barriers to mining. EU Horizon 2020 past initiatives, including notably the INFACT project (INFACT 1\&2, 2017) focussed on developing innovative exploration technologies and undertook research on the factors driving resistance to mine exploration in Europe. INFACT and other Horizon 2020 projects explored the importance of social and environmental acceptability of the sector and the challenges faced in building mutual awareness and trust between communities, society and the mineral exploration and mining sectors with the aim of securing consent to mine. By the middle of 2020 some H2020 mining related projects, notable the MIREU project, became the target of a coalition of anti-mining organisations and networks. This, and the criticism from an increasingly connected lobby wrongly categorised in the author's view as, "anti-mining", suggests that while economic, environmental and health and safety performance had been focussed on, social performance was not considered to the same extent (MIREU 1). The causal linkage between social performance and social licence is but poorly understood (Proctor 2021). Social considerations such as cultural values, diversity and heritage concerns have been regarded within the mining sector as NIMBYism rather than important social values by affected communities. This was a key argument in the "Joint civic statement" on the European Horizon 2020 project MIREU (2020), signed by signatories from Bosnia, Finland, Ireland, Portugal, Slovakia, and Spain, in a well-crafted academic paper sent as a complaint to the European Commission (EC). The focus of the complaint was the MIREU project's lack of community consultation with the construction of their Social Licence to Operate (SLO) guide, developed as a deliverable through the EU funded Horizon 2020 project. There has been a distinct increase in the number and collective cohesiveness of anti-mining groups across Europe, most of which attribute existing land use and potential damage to the environment, to be at the core of their concerns. Alongside this addressing the lack of positive engagement by mining companies, paucity of relationships between the mining sector and stakeholders and low levels of trust towards the mining sector, were identified (INFACT 1,2017) as critical to moving mining interests forward. This raises huge issues about the likelihood of mining companies obtaining and retaining an SLO within a European context. Mining conflict could become a focus for those interested in undermining EU resilience and attacking the political consensus, through the galvanising of "anti-mining" sentiment. The question is, is doing nothing an option? 


\section{A Social License to Explore and Operate}

The term Social Licence to Operate (SLO) was first coined by a mining industry executive Jim Cooney in the last century (Cooney, 2017) and Boutilier, (2017:2) makes the point, that Joyce and Thomson (2000) made the first attempt to define an existing social licence to operate within the academic literature as being,

"When a mineral exploration or mining project is seen as having the approval, the broad acceptance of society to conduct its activities."

Recently, the term Social Licence to Operate (SLO) has globally become accepted in the mineral and mining sector to define the necessary requirement of a supportive or compliant host community. This can avert costly problems dealing with protests, boycotts, social media storms, and attacks on the reputation of key stakeholders, which might ultimately stop mining operations. The vagueness, lack of criteria and measurability of social license presents a concern (Bice \& Moffat 2014). The financial industry appears to have a fragile understanding of the relationship between environmental and social governance and SLO. After a few years of the international financial risk management company EY, having SLO as the number one risk, in 2022 it has swapped places at number four with "Environmental and Social Governance (ESG) (EY1 2021). The disaggregating of ESG and SLO will likely be remedied in time when aspects of how ESG effectiveness at delivering SLO for mining companies, is better understood. However, one views or categorises SLO as a business risk, whether first or fourth, it is obviously a serious matter to consider in relation to the importance of the extraction of CRMs. As a social theorist, looking closely at the SLO concept, there has been, due to the attendant complex social and political chemistry and its embeddedness in "stakeholder theory" (Elson, \& Goossen, (2017) Mansell (2013a), an apparent fragmentation of focus and a proliferation of definitions. Other concepts associated with a SLO are "social risk", "business risk" having emerged from "non-technical project risk" and "socio-political risk" (Parsons, Lacey, \& Moffat. 2014.) Kemp (2016) examined the notion of business risk to mines emerging from social risk through a "bounce"; the impacts of the mines on communities causing a corresponding rise in the level of business risk through some yet, uncontainable process. Sandy Worden (2016) suggests that "social risk" should perhaps be more correctly used to descript the risk to the community from mining and prefers the term "social acceptability risk", a term coined by Miller and Lessard in 2001, to define that risk most closely associated with social licence. The question at hand may be "risk" to whom, communities, the mining sector, or the EU more generally? There are also theoretical perspectives supporting the reconceptualising of the physical and conceptual boundaries of "the project" that we could explore, if we want to understand the relationships and complexities around a specific mine project rather than as part of an overarching theory (see Sage, Dainty, \& Brookes. 2011). Theoretically the arguments carry us back to a critique of stakeholder theory and who creates company value. There are a range of debates that are likely to grow as the mining sector recognised that their existing conceptualisation of the value creation paradigm, excludes the recognition, that a lack of active cognizance of communities' sovereignty and engagement to reach acceptability in terms of operational processes, can bring mine operations to an abrupt halt. The author's doctoral work in developing a new theoretical model of social licence, the Social Licence Settlement Model (SLSM) (Proctor 2021), examined the relationship between the collapse of the political settlement around mining in Romania, as that country become increasing integrated into EU processes through the ascension process. The SLSM is assembled as a paradigm using a range of theoretical tools and characterised the SLO as essentially, a balancing act across society. The SLSM enables the identification of relationships across, what we can loosely call stakeholders. The model was used by the author and Dr C MacCallum to create a Social Licence to Operate Index for a financial industry partner, mapping, overlaying, and creating metrics for critical relationships using extensive experience from the field as well as academic research. Once for example, you recognise the role of the community in legitimising international NGO's and how that can put pressure on those who in part finance the mine (The Lender), you can develop an index of stressors for that field. Similarly, one can investigate the relationship between international rights frameworks and the State and develop a similar list of stressors. Yet it does more than representing a dynamic framework for understanding SLO and what might impact on its stability. The SLSM provides, like the notion of political 
settlement itself, a shorthand or accessible concept, promoting a wholistic balancing of risks that mining sector board executives can weigh. Mining sector board members are unlikely to be interested in the finer points of Actor Network Theory and the building and changing process of the assemblage (Callon, M. 1986a Callon, M. 1986b) that underpin the model. So, whilst it has utility in supporting the design of a system of metrics to determine and predict SLO, it likewise has utility as a tool for understanding more generally what local SLO vulnerabilities might be.

\section{FIGURE 1 SOCIAL LICENCE SETTLEMENT MODEL (SLSM) PROCTOR 2021}

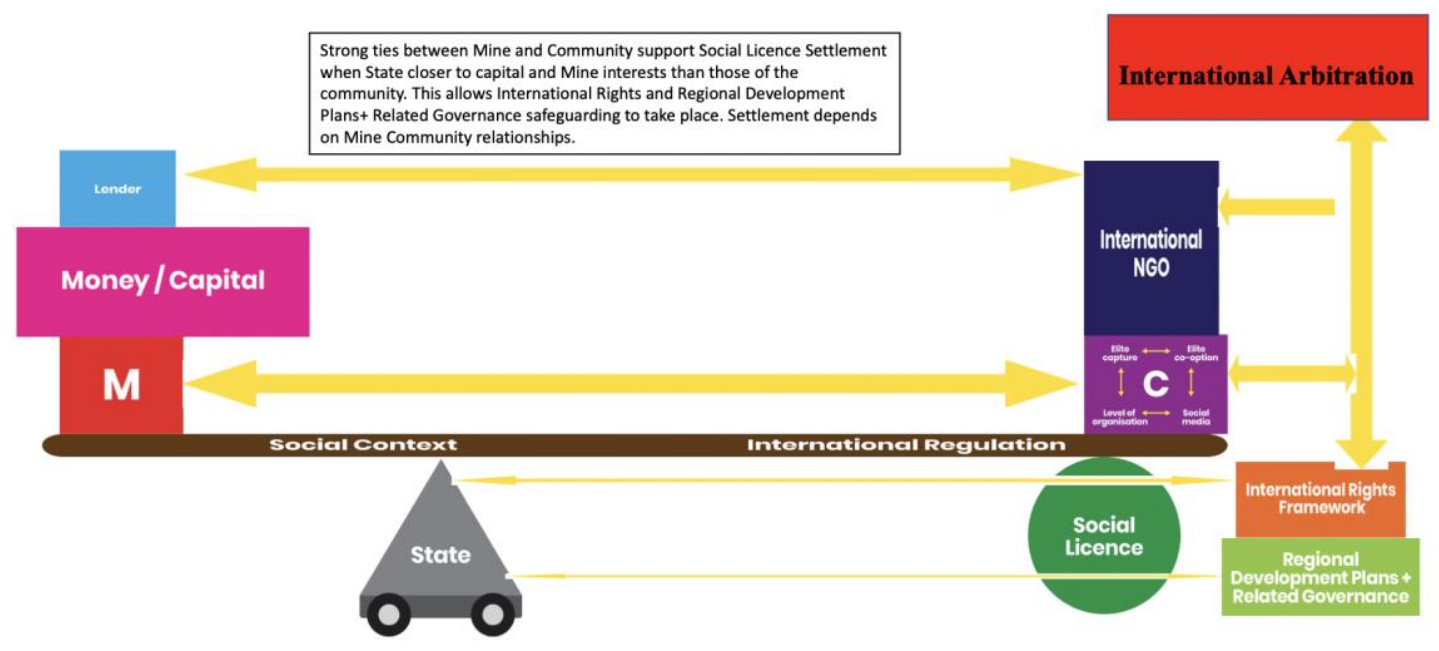

Research undertaken in 2017 as part of the author's doctoral work in Romania's neighbour Serbia, drew analogies between the two countries and forecast a repeat of an increasing of hostility towards mining projects in Serbia, as had occurred in Romania. The thesis predicted the emergence of similar forces in Serbia, with the mobilisation of civil society against mining, environmental damage, and the political elite, as it aligned with the EU Acquis Communautaire (the EU members rulebook) and becoming the recipient of more and more transparent EU funding, just as previously happened in Romania. (Proctor 2021, Parau, 2006\&2009). Rio Tinto are currently experiencing this in Serbia (Media 1), partly precipitated by a failure to develop effective local and regional engagement processes that differentiate them and their activities nationally from a range of Chinese firms operating with questionable social and environmental practices in other parts of the country (Media 2) Partly also, if one accepts the word of protestors, because they have already caused pollution, cannot be trusted, and have the politicians in their pocket- who they argue have the electorate in their pocket through the ruling party's wealth. Whether this is true or untrue appears, if we look at the process that stopped Gabriel Resources' (GR) Rosa Montana project, largely irrelevant. GR where blatantly misrepresented by what become an international protest movement (Proctor 2021) and due to a the lack of a legitimate counter claim or local and internationalised legitimised narrative being allowed to develop, the author argues, the forces around the social licence become unstoppable. Popular anti-mining protestors' lack of faith in the integrity of the political system appears to have been used in Romania as a lever by the EU, to expedite environmental and regulatory changes, as that country sat in a similar place in the process of joining the EU as Serbia does now (Proctor 2021, Parau, 2006\&2009). The political settlement required to deliver a SLO for Rio Tinto in Serbia, if analysed using Proctor's SLSM, will elude them in the long term, unless they change tack and move away from thinking a state licence will protect them. Unless Rio Tinto start learning from historical events, they are likely to find themselves in a similar and likely worse situation than Gabriel Resources in neighbouring Romania, where the politicians eventually responded to international and national pressure to remove the mining permit re Rosa Montana, despite much local community support for the mine. The political settlement become a national and 
international one, arguably leaving both local communities and the environment as the losers. No matter how strategic any mining project might be, a politician's first focus is to retain power. In Romania with Rosa Montana, the licencing process arguably became a political rather than a technical compliance one, or at least that what Gabriel Resources are arguing at the investment tribunal arbitrating the Bilateral Investment Treaty against the Romanian government. The right and wrongs of this are ongoing through international tribunal with nearly \$3B on the table (see BIT 1 for details).

Ultimately trust for mining activities in Europe is hard to gain, but easy to lose. Consent is not a oneoff activity; peoples' minds can change as can political decisions when a context is changing, so for mining to be accepted, consent must be continually revisited and potentially redefined or renegotiated. Trust between the state and a company is essential to facilitate sustainable institutions, and trust between a company and civil society is required to enable economic development. There also needs to be trust between state institutions and civil society to enable accountable governance. The current civic and political dynamism within the Western Balkans makes this difficult but the lessons should be learned across the EU and wider Europe. Only when a set of positive relationships involving, the mine company, civil society and the state occur together, can full acceptance of mining and an SLO be achieved and made resilience to withstand shocks, trends, and other external factors.

\section{Who, How, What?}

This paper makes the case for the creation of a Common European Mining Policy (CEMP) embedded within European Rural Development Policy. Without appropriate institutions and processes across the EU, how are the conditions for a political settlement around mining locally, expected to be created? Policy makers and government have an important role to play in mineral exploration within the EU. There is a very wide variety of governance models for minerals and mining across the nations of Europe, even between countries with close ties and otherwise similar legislature, such as in the Nordic region. Finland is currently the only European country that integrates social and environmental aspects in their mineral exploration legislation, demonstrating an awareness of the interrelationship between exploration, social and environmental activities.

Currently the EU Environmental Impact Assessment Directive provides a comprehensive legislative framework for environmental, health and safety performance, but not social performance. This is a gap that has resulted in local communities facing mining projects across Europe turning to environmental regulatory instruments such as Natura 2000, to stop mineral exploration projects, as there is no European-wide social regulatory framework regarding mining. Revocation of exploration or mining licences occurs at a national level and, when instigated by communities, nearly always involves them utilising EU environmental regulations and mobilising the local political power. The EU is ill prepared for the process of enabling mining, given that the rules for financing the mining sector with Green Deal EU monies have not yet been defined. There is currently no guidance for investors on how to define a potential mining project with a social licence to operate. The EU Technical Investment Group (TEG 2020) identified the need for a mining taxonomy. Such a taxonomy covers many sectors in the EU and identified critical issues that must be addressed before investment of EU sourced funds can be committed. The TEG 2020 group recognised the complex nature of doing this for mining and their inability in terms of time and expertise to complete this task. The lack of a taxonomy guidance framework for mining is in marked contrast to taxonomy guidelines relating to the financing of agriculture, energy production and a myriad of other activities.

Enabling socially sensitive financially investment in mining is critical. Likewise understanding that the current business model for mining, a rather colonial one, is ill equipped to gain and retail SLO within Europe. Currently a deal is struck between a mining company, usually with central government, for the company to extract what is a sovereign resource. This approach is failing for numerous reasons outlined earlier. To enable both the extraction of CRM identified as critical and for communities to be able to give consent, two factors need to change if we accept a SLSM as a valid paradigm. Firstly, host communities need the ability to say NO to mining. This also gives them the capacity to say YES but places an emphasis on front loading investment in consultation, engagement and in developing local institutions that can develop and build a political settlement. Defining locally how a mine could gain SLO, is a process that can 
only be delivered through a deliberative dialogue with potential host communities, and this takes time. An underground mine for example, in a particular locality, may be more costly than a pit or open caste mining approach and make the business and financial model proposed by a mining company inoperable. Yet this approach might allow the addressing of social and environmental objectors and enable the CRM's to be extracted whereas a pit or open caste process would galvanise resistance. The benefits are of extracting the CRM and the sovereign resource value, redistributed not to reward shareholders of an extraction company but to create community benefit and wealth. Wealth in the form of taxable income for the EU and prosperity for localities without a risk of a poor environmental legacy, is an alternative metric for benefit, to mining company profits and shareholder dividends paid potentially outside the EU. Both financially and governmentally, only the EU could fulfil the role of policy enabler. It is unlikely that a mining company could afford to or get consent from shareholders to invest in what might be a 10 year plus programme of community learning, local capacity building and the development a shared local and regional rural development vision. The question will be, is there a deep enough understanding and a strategic enough of a vision within the EC, to support the dedication of considerable financial resources in building local democratic institutions supporting local and regional development.

Zasada, Häfner, Schaller, van Zanten, Lefebvre, Malak-Rawlikowska and Viaggi (2017:9) in their excellent review of the literature in support of a new conceptual model to integrate the regional context in landscape policy, management and contribution to rural development made several pertinent points regarding the arguments herein. They said that for.

"Landscape management [to] deliver optimal benefits, landscape policies should be codesigned in adaptive governance approaches with local farmers, communities and stakeholders, which acknowledges the complexity and dynamism of social-ecological systems (such as landscapes) (de Loë et al., 2009). García-Martín et al. (2016) have clearly shown that bottom-up civil society initiatives are able to foster holistic approaches of landscape level management, which include multiple sectors and scales relevant to the system."

Adaptive governance approaches that maximise benefit from rural areas must engage a variety of stakeholders. Mining invariable occurs with a rural setting and perhaps those institution created through European Rural Development Policy might be best utilised to support an engagement about subterrain rural assets and how they might best be not only extracted but used for local benefit. Zasada et al's (2017:1) analysis was that.

"Sustainable management of agricultural landscapes, partly driven by landscape policies (i.e., agri-environmental policies (AEP) and regulations), is increasingly under-stood to benefit rural vitality in a more integrative way (Cooper et al., 2009;)

The complexity of the social context of these agricultural landscapes in which mineral exploration takes place, is often poorly understood, and consequently not considered as a consequential issue affecting mining projects. This results in a lack of common ground or understanding and often feeds a culture of dependency and antagonism with rural communities, as mines edge forward towards being operability. Both community and companies end up in a situation where the community is hosting an exploration or mining project that is uninvited and an unwelcome guest. At an EU level, present early-stage engagement between actors in a mine locality are from association with the Aarhus declaration which requires consultation on environmental matters. At a national level, as most of the EU states are OECD members, subsidiarity results in mineral exploration and mining projects being governed by local and national planning law, which as a rule is not fit for purpose, for the mineral sector. If an area has not had a mining project before we should not expect its local planning law to be adequate.

Change to enable access to CRMs in Europe, requires a reframing of the relationships between mineral exploration companies, the communities that host them and the governance structures that permit and 
regulate them. This should involve a determination of shared values and common goals that could be achieved and supported by different stakeholders or rights holders and the respective duty bearers. This in turn requires effective and meaningful engagement from the outset and for such engagement to be regarded as an investment instead of a cost. At a workshop in Cardiff 2017, hosted by SRK Exploration, the author proposed an EU approach to investing in localities and local capacity building, regarding supporting mining access to CRMs. This was met with derision by a US colleague who said, "you can't subsidise mining". My reply was that the EU have been subsiding food production for some 50 years and not just in terms of volume but in terms of the added value the production gives. Protecting historic landscapes, environmental benefits, and social conditions, played a central role to the Common Agricultural Policy (CAP) once food shortages had been addressed. This type of thinking needs to be applied concerning securing access to CRMs or Europe is opening the door to unfriendly states investing in local politics and the vulnerabilities outlined earlier. In parallel to this Europe is facing an unprecedented and coordinated backlash against mineral exploration and mining projects, fuelled in part by environmental concerns, but dominated by the value people ascribe to their natural resources and sense of place. Understanding these social and cultural values and what drives them is essential. The behavioural change from the mining sector required for CRM exploration and extraction to be fully acceptable, will likely require a new mining business model from participating companies. Mineral exploration and mining projects that put shareholder profit first are not likely to be sustainable or resonate with the Green Deals ambitions or EU societal requirements. Mineral exploration in Europe is dominated by junior companies who for the most part, seek to take an exploration project to resource estimate or development permitting and then sell it on. A project can pass through more than 10 companies before it becomes a productive mine, each transaction generating profit and normally leaving a legacy of potential broken or unhonoured commitments in its wake. Funding is sourced primarily through private equity and the CRIRSCO codes like PERC, are used to report exploration results and resource estimates. There are very few checks and balances. CRIRSCO, which was formed in 1994 is a grouping of representatives of organisations that are responsible for developing mineral reporting codes and guidelines in Australasia (JORC), Brazil (CBRR), Canada (CIM), Chile (National Committee), Colombia (CCRR), Europe (PERC), India (NACRI), Indonesia (KOMBERS _ KCMI), Kazakhstan (KAZRC), Mongolia (MPIGM), Russia (NAEN), South Africa (SAMREC), Turkey (UMREK) and the USA (SME). The combined value of mining companies listed on the stock exchanges of these countries accounts for more than $80 \%$ of the listed capital of the mining industry. Europe's PERC in a very progressive move, have very recently included a social measure attaching importance on early local community/stakeholder engagement with resource discovery, arguably recognising reality in business terms.

The Horizon 2020 INFACT project had worked with PERC and the wider CRIRSCO network to support greater scrutiny of environmental, social and governance factors and as these moves to be adopted, will contribute towards an attitudinal change in the sector. Yet the changes will likely make it more difficult to ignore obscure or obfuscate social risk and will potential revel SLO fragility from potential investors and that will likely affect investors' appetite for mining in Europe. Access to CRM may be more important to the EU than the sacred cow of market forces and financial neoliberalism.

\section{CONCLUSION}

There is a developing crisis within Europe concerning host community consent to mining CRMs as dissent becomes increasingly muscular and networked. This is part of a global phenomenon but the politics of the EU and the lack of adequate methods for engaging rural citizens in a deliberative dialogue will, as supported by the SLSM predicated on political settlement, result in CRMs staying in the ground across Europe. This will have profound implications for the EU's competitiveness and potential it's cohesion as an entity. If adequate resources are deployed and political will applied utilising mechanisms in the form of rural development strategies that already exist, given what we know about SLO, a crisis might be averted in the middle to long term. Community processes are slower than those of business and no magic bullet is going to quell the rising tide of civil society against the mining sector. This issue is a rich vein of political 
capital for Members of the European Parliament (MEP), yet if ignored, offers external states opportunity for disrupting the EU competitiveness. The EU has so far failed to conceptualise that the issue is a political one, one entailing the engagement of citizens and not one requiring only a quick technical fix. Part of the solutions is likely to represent the retreat from the current mining business model in Europe which could be characterised as a colonial mining model. More EU intervention and citizen engagement will likely lead to the development of new service mining company sector that are directly funded by member states. These new forms of industry will not be gambling on securing a slice of sovereign wealth from underground but paid for work undertaken from the resulting sovereign wealth, enabling a wider rural local and regional plan, whilst extracting CRMs for Europe's industries. Proctor's SLSM offers a way to identify, conceptualise and ultimately address and resolve the complex relationships necessary for a SLO to be created and stay stable.

\section{ACKNOWLEDGMENTS}

The collaboration of Dr Cathryn MacCallum (Sazani) and the opportunities provided for research by SRK Exploration (Cardiff,UK.), the Horizon 2020 INFACT project and Professor Vladimir Simic of Belgrade University, were critical to the research underpinning this paper.

\section{REFERENCES}

Bice, S., \& Moffat, K. (2014). Social licence to operate and impact assessment. Impact Assessment and Project Appraisal. Taylor and Francis Ltd. https://doi.org/10.1080/14615517.2014.950122

Bice, S., Brueckner, M., \& Pforr, C. (2017). Putting social license to operate on the map: A social, actuarial and political risk and licensing model (SAP Model). Resources Policy, 53, 46-55. https://doi.org/10.1016/j.resourpol.2017.05.011

BIT 1. (n.d.). Retrieved from https://www.italaw.com/cases/4721

Bobba, S., Carrara, S., Huisman, J., Mathieux, F., \& Pavel, C. (2020). Critical Raw Materials for Strategic Technologies and Sectors in the EU - a Foresight Study. European Commission, p.100. https://doi.org/10.2873/58081

Boutilier, R.G. (2017, November). A Measure of the Social License to Operate for Infrastructure and Extractive Projects. SSRN. http://dx.doi.org/10.2139/ssrn.3204005

Callon, M. (1986a). Some elements of a sociology of translation: domestication of the scallops and the fishermen of St Brieuc Bay. In J. Law (Ed.), Power, action, and belief: A new sociology of knowledge? (pp. 196-223). London: Routledge.

Callon, M. (1986b). The sociology of an actor-network: The case of the electric vehicle. In M. Callon, J. Law, \& A. Rip (Eds.), Mapping the Dynamics of Science and Technology: Sociology of Science in the Real World (pp. 19-34). Houndmills, Basingstoke, Hampshire: Macmillan.

Cooney, J. (2017). Reflections on the 20th anniversary of the term 'social licence'. Journal of Energy \& Natural Resources Law, 35(2), 197-200.

Cooper, T., Hart, K., \& Baldock, D. (2009). The Provision of Public Goods through Agriculture in the European Union. London.

de Loë, R.C., Armitage, D., Plummer, R., Davidson, S., \& Moraru, L. (2009). From Government to Governance: A State-of-the-Art Review of Environmental Governance. Final Report Prepared for Alberta Environment, Environmental Stewardship.

Elson, C.M., \& Goossen, N.J. (2017, June 1). E. Merrick Dodd and the rise and fall of corporate stakeholder theory. Business Lawyer. American Bar Association. Environmental Relations. Rob de Loë Consulting Services, Guelph.

Endl, A., Tost, M., Moser, P., Berger, G, Gottenhuber, S L, Taxiarchou, M, . . Frishammar, J. (2019). Policy drivers and barriers for sustainable mining innovations in the EU: A case Study Analysis. European Union's Horizon 2020 research. 9th International Conference on Sustainable Development in the Minerals Industry. Sydney, Australia, 27-29 May 2019. 
Eureporter. (2021, April 12). Rio Tinto's gung-ho mining exploration on the border of the European Union should worry us all. Retrieved from https://www.eureporter.co/world/serbia/2021/04/12/rio-tintos-gung-ho-mining-exploration-onthe-border-of-the-european-union-should-worry-us-all/

EUROPA. (2020, March). Taxonomy: Final report of the Technical Expert Group on Sustainable Finance. Retrieved from https://ec.europa.eu/info/sites/default/files/business_economy_euro/banking_and_finance/docume nts/200309-sustainable-finance-teg-final-report-taxonomy_en.pdf

EY1. (2021). Retrieved from https://www.ey.com/en_gl/mining-metals/top-10-business-risks-andopportunities-for-mining-and-metals-in-2022U

García-Martín, M., Bieling, C., Hart, A., \& Plieninger, T. (2016, December 15). Integrated landscape initiatives in Europe: Multi-sector collaboration in multi-functional landscapes. Land Use Policy, 58, 43-53. ISSN 0264-8377. https://doi.org/10.1016/j.landusepol.2016.07.001

Herrington, R. (2021, June 1). Mining our green future. Nature Reviews Materials. Nature Research. https://doi.org/10.1038/s41578-021-00325-9

INFACT 1. (n.d.). Retrieved from https://www.infactproject.eu/wpcontent/uploads/2018/07/INF_SRK_Expert-Stakeholder-Survey_T2.4_-V1.3.pdfACT

INFACT 2. (n.d.). Retrieved from https://www.infactproject.eu/wpcontent/uploads/2018/06/INF_ATC_D_2.3.Reputation-report_01.pdf

Joyce, S., \& Thomson, I. (2000). Earning a social licence to operate: Social acceptability and resource development in Latin America. CIM Bulletin, pp. 49-53

Kemp, D., Worden, S., \& Owen, J.R. (2016). Differentiated social risk: Rebound dynamics and sustainability performance in mining. Resources Policy, 50, 19-26. https://doi.org/10.1016/j.resourpol.2016.08.004

Lacey, J., Malakar, Y., McCrea, R., \& Moffat, K. (2019). Public perceptions of established and emerging mining technologies in Australia. Resources Policy, 62, 125-135. https://doi.org/10.1016/j.resourpol.2019.03.018

Mansell, S. (2013). Shareholder Theory and Kant's "Duty of Beneficence." Journal of Business Ethics, 117(3), 583-599. https://doi.org/10.1007/s10551-012-1542-9

Mason, C.M., Paxton, G., Parsons, R., Parr, J.M., \& Moffat, K. (2014). "For the benefit of Australians": Exploring national expectations of the mining industry. Resour. Pol., 41, 1-8. https://doi.org/10.1016/j.resourpol.2014.01.008

Moffat, K., Pert, P., McCrea, R., Boughen, N., Rodriguez, M., \& Lacey, J. (2017). Australian Attitudes toward Mining: Citizen Survey - 2017 Results. CSIRO, Australia. Retrieved from https://www.csiro.au/en/Research/MRF/Areas/Community-and- environment/Understandingcommunity-attitudes/Australian-attitudes-to-mining- 2017

Parau, C.E. (2006). The interplay between domestic politics and Europe: How Romanian civil society and government contested Europe before EU accession.

Parau, C.E. (2009). Impaling Dracula: How EU accession empowered civil society in Romania. West European Politics, 32(1), 119-141. https://doi.org/10.1080/01402380802509917

Parsons, R., Lacey, J., \& Moffat, K. (2014). Maintaining legitimacy of a contested practice: How the minerals industry understands its "social licence to operate." Resources Policy, 41(1), 83-90. https://doi.org/10.1016/j.resourpol.2014.04.002

Proctor, M. (2021). A theoretical model for social licence to operate for the mining sector in South Eastern Europe. DOI: 10.23889/SUthesis.57748

Proctor, M., \& MacCallum, C. (2020). The Canary in the Cage: Community Voices and Social License to Operate in Central Eastern Europe. Journal of Applied Business and Economics, 22(14). https://doi.org/10.33423/jabe.v22i14.3968

Sage, D., Dainty, A., \& Brookes, N. (2014). A critical argument in favor of theoretical pluralism: Project failure and the many and varied limitations of project management. International Journal of Project Management, 32(4), 544-555. https://doi.org/10.1016/j.ijproman.2013.08.005 
Scribd. (n.d.). Joint Civic Statement On The European Horizon 2020 Project MIREU. Retrieved from https://www.scribd.com/document/473473651/Joint-civic-statement-on-the-European-Horizon2020-project-MIREU

van der Plank, S., Walsh, B., \& Behrens, P. (2016). The expected impacts of mining: Stake-holder perceptions of a proposed mineral sands mine in rural Australia. Resource. Pol., 48, 129-136. https://doi.org/10.1016/j.resourpol.2016.03.005

Vuksanovic, V. (2021, July 16). How Serbia Became China's Dirty-Energy Dumping Ground. Foreign Policy. Retrieved from https://foreignpolicy.com/2021/07/16/serbia-china-bri-coal-copper-dirtyenergy-dumping-ground/

Worden, S. (2016). Is the mining industry misdiagnosing social risk? Risk and Resilience Mining Solutions, pp. 375-389.

Zasada, I., Häfner, K., Schaller, L., van Zanten, B.T., Lefebvre, M., Malak-Rawlikowska, A., .. . Viaggi, D. (2017). A conceptual model to integrate the regional context in landscape policy, management and contribution to rural development: Literature review and European case study evidence.

Geoforum, 82, 1-12. https://doi.org/10.1016/j.geoforum.2017.03.012 